\title{
フレキシブルアームに対する 仮想受動関節モデルの有効性の検討
}

\author{
吉川 恒 夫* 田 村 正 人* \\ Study on Effectiveness of Virtual Joint Model for Flexible Manipulators
}

Tuneo Yoshikawa* and Masato Tamura*

\begin{abstract}
In this paper, we verify the effectiveness of virtual joint model, which is one of the lumped parameter model, for the flexible manipulators. First, the outline of the virtual joint model approch is given, then a planer 2-DOF (degree of freedom) flexible manipulator is modeled by using virtual joint model. Second, the same manipulator is modeled by using distributed parameter model. Then experiments and simulations using the both models are performed. The effectiveness of virtual joint model is verified by comparing the dynamic behavior of each model with that of the real arm.
\end{abstract}

Key Words: Flexible Manipulator, Modeling, Lumped-Parameter Model, Distributed Parameter Model

1.はじめに

近年, 産業用ロボットに対しては軽量化抢よび高速化の要求 が，また宇宙用ロボットに対しては長尺化および軽量化の要求 が高まっている。このようにリンク部が非常に軽量化され，そ のために剛性が低下したアームをフレキシブルアームと呼ぶ. フレキシブルアームでは, リンク部の柔軟性による振動やたわ みが発生するので，これらを抑制・補償することが問題となる。

フレキシブルアームの制御則構築には, まずその動力学的挙 動を記述するためのモデルが必要となる。フレキシブルアーム の研究の初期から現在まで, モデルには分布定数系モデルがよ く用いられてきた $[1] 〜[5]$. これは柔軟なリンクを偏微分方程式 で記述される分布定数系としてモデル化する方法で, 最も直接 的で正確なモデルが可能とされてきた。しかしモード関数法で 有限次元モデルを得ようとすると，モード関数が特定の境界条 件に依存するという難点を有しており, 複雑な形状のリンクや 多リンク多自由度アームでは得られるモデルが非常に複雑にな り，そのモデルに基づく制御則の構築も現実的ではない. 故に 最近ではより実時間での制御に向いていると考えられる集中定 数系によるモデリング法がいくつか提案されている [6]〜 [12].

集中定数系によるモデリングは弾性体をいくつかの剛体要素 に分割し、アームのもつ柔軟性をその剛体要素を連結するバネ として表現する方法である。この集中定数系モデルの問題点と してパラメータ決定の困難さが挙げられている [5]. 多くの集中 定数系モデルがばね定数としてリンクの曲げ剛性を用いている

原稿受付 1998 年 3 月 19 日

*京都大学工学研究科

${ }^{*}$ Faculty of Engineering, Kyoto University
が [6] [9]〜 [12]，これは分布定数系モデル同様複雑な形状のリン クや一様でないリンクへの適用が困難である。またリンクを複 数に分割した場合の各要素の長さなどのパラメータの決定につ いては考察されていない $[10]$.

こうした集中定数系モデルの中で吉川らの提案した仮想受動 関節モデル [7] [8] は，実際のリンクの特性值を測定し，それに 対応するモデルの特性值が実機に近づくようにパラメー夕を決 定するものであり，実際のアームにより近い挙動を示すような モデルが得られると期待される。また全体の系は各リンクを個 別にモデル化したものを連結するため，分布定数系モデルのよ うな複雑な境界条件を考慮する必要がないことや, 複雑な形状 のリンクや一様でないリンク拈よびパラレル機構をもつマニ ピュレータなどにも容易に適用できるという利点もある。

以上のことをふまえ本論文では，一様なリンクをもつ平面 2 自由度フレキシブルアームを用いて, 分布定数系モデルおよび 仮想受動関節モデルによるシミュレーションと実機の挙動を比 較することで，仮想受動関節モデルのフレキシブルアームに対 する有効性について検討する†。同様の集中定数系モデルの評 価は金らも行っているが [10], 1 自由度 1 リンクアームの応答 の比較のみであり多リンク多自由度アームでの評価は行われて いない。

†一様なリンクをもつアームを対象としたのは, 本論文の目的が, 仮想受 動関節モデルと分布定数系モデルとの比較を通じて仮想受動関節モデ ルの有効性を検討することであり, 分布定数モデルが得られる必要が あるためである。一様でないリンクをもつアームに対する仮想受動関 節モデルの同定については，文献 [8]で扱っているが，このようなアー ムに対して分布定数系モデルを与える方法は確立されて扮らず，本論 文で行ったような比較は困難であることに注意されたい。 


\section{2。対象とするフレキシブルアーム}

本論文で対象とするフレキシブルアームの概観および実験シ ステムの模式図をそれぞれ $\mathbb{F i g}$ 1，2 に示す。台座側からフレ キシブルリンクをリンク 1,2 とし，能動関節を関節 1,2 とす る.リンク 1,2 とも円形断面の一様なリンクで, 材質は $\mathrm{S} 45 \mathrm{C}$ 炭素鋼である。また、リンク 1 は直径 $0.013[\mathrm{~m}]$, リンク 2 は 直径 $0.008[\mathrm{~m}]$ である。各関節には光学式のエンコーダが装備 されておりこれを用いて各関節の回転变位を測定する。また， 振動の様子の観察には，実機，シミュレーションとも計测が容 易で振動の様子をよく表す指標として加速度を用い，リンクに 対して垂直な万向の加速度を測定する。そのためリンクの先端 には加速度センサが取り付けてあり，リンクに対して垂直な方 向の加速度を測定する。これらのセンサより得たデータをカウ ンタボード, A/D ボードを介してホストコンピュータに取り 込み, 各関節変位, 加速度のデータをとる。また，ホストコン ピュータで各関節の関節入力を計算し，D/A ボードを通して アンプに送り，各関節に供給する。各関節はDC サーボモータ をハーモニックドライブ減速で用いており，その減速比は関節 1，2 ともに 1：100である。ホストコンピュー夕は，NEC 製 PC-9821Xa（Pentium 120 MHz）を用いる。

なお，制御装咀はPD 制御実験の場合に用いるが，それ以外

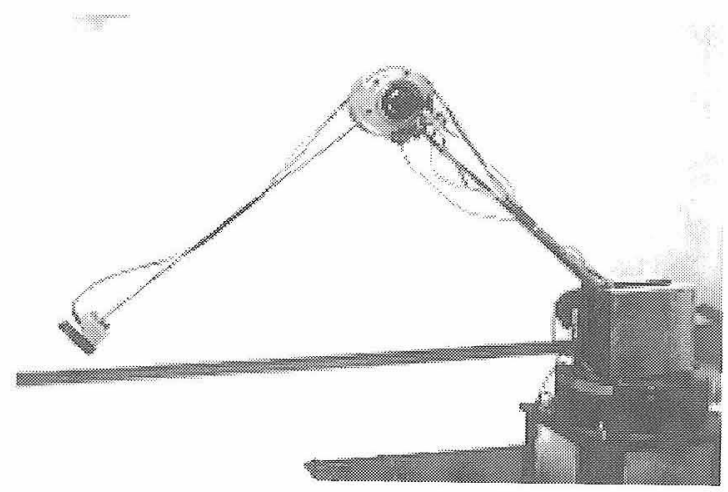

Fig. 1 Overview of the arm

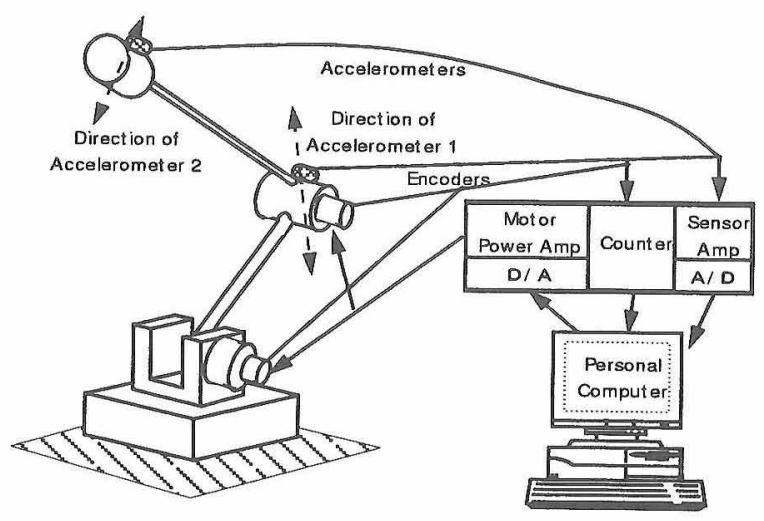

Fig. 2 The experimental system
の実験には用いていない。

\section{3. 仮想受動関節モデル}

\section{1 モデルの構造}

仮想受動関節モデルによるモデリング [7] [8] は，アームを構 成する各リンクの柔軟性を Fig。3に示すように複数個の仮想 的な剛体リンク（仮想剛体リンク）がバネ，ダンパなどの仮想 的な受動的関節（仮想受動関節）によって結合されたものとし て近似し，全体のアームは，それらを連結したものとしてモデ ル化する方法である。

本論文で扱うフレキシブルアームを仮想受動関節モデルを 用いてモデル化するとFig.4のようになる。Fig.4のように リンク $i$ を $N_{i}$ 個の仮想剖体リンクに分割したとき，台座側 から仮想風体リンク $(i, 1),(i, 2), \cdots,\left(i, N_{i}\right)$ とし，仮想リンク $(i, j)$ の根元に付いている仮想的な関節を仮想受動関節 $(i, j)$ とする。

このモデルは，仮想刷体リンクの長さ，質量や慣性テンソル， 仮想受動関節のバネ定数や減衰係数などの定数パラメータを含 む.これらの定数パラメータの決定方法は種々考えられるが，そ の一方法としてリンクの固有振動数や静的荷重に対するたわみ などの特性值が実機とモデルとでできるだけ一致するようにモ

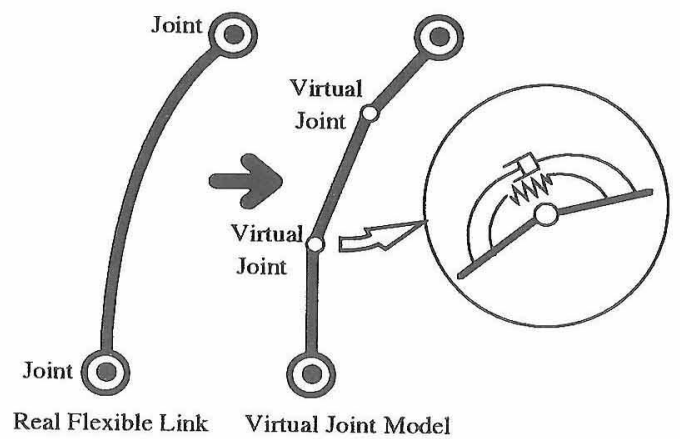

Fig. 3 Modeling of flexible link using virtual rigid links and passive joints

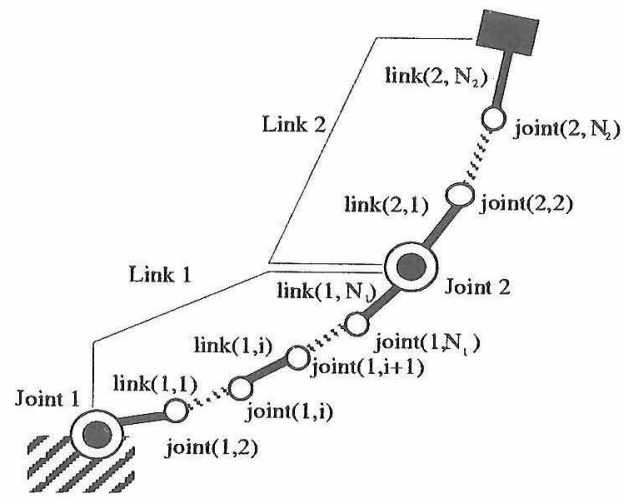

Fig. 4 Model of a planer 2-DOF flexible manipulator using virtual joint model 
デルのパラメータを定めるという方法が提案されている $[7][8]^{\dagger}$. この方法ではまずアームの各リンクの特性值を同定実験によっ て測定し，これらを $\boldsymbol{\alpha}_{r}=\left[\alpha_{r 1}, \alpha_{r 2}, \cdots\right]^{T}$ とする。また $\boldsymbol{\alpha}_{r} に$ 対応するモデルからの計算値を $\boldsymbol{\alpha}_{m}=\left[\alpha_{m 1}, \alpha_{m 2}, \cdots\right]^{T}$ とし， 各デー夕の重要度を表す重みを $w_{i}$ としてモデルの適合度を表 す評価関数

$$
J=\sum_{i} w_{i} \frac{\left(\alpha_{r i}-\alpha_{m i}\right)^{2}}{\alpha_{r i}^{2}}
$$

が最小となるパラメー夕を最適值として採用する。式（1）を 最小とするパラメー夕決定の具体的な方法については 3.3 節で 述べる。

\section{2 モデルの特性値}

本節ではフレキシブルリンク $i$ の仮想受動関節モデルに対す るリンクの特性值を求める。本論文ではリンクの分割数 $N_{i}$ を リンク 1,2 とも 4 とする圢。また, 平面 2 自由度アームを报 うので, リンクの挙動は平面内に限られているものとする。根 元側の仮想剛体リンクが固定され，もう一方の端の仮想リンク が自由である場合，リンク $i$ は Fig. 5 のようなモデルとなる.

まず動特性について考える。一端固定多端自由の場合のリン クの振動の運動方程式は，振動振幅が十分小さいとして非線形 項を無視し，また粘性に関する項も固有振動数にほとんど影響 を与えないとすると次式のようになる。

$$
\begin{aligned}
& {\left[\begin{array}{lll}
M_{11} & M_{12} & M_{13} \\
M_{12} & M_{22} & M_{23} \\
M_{13} & M_{23} & M_{33}
\end{array}\right]\left[\begin{array}{l}
\ddot{\phi}_{i 2} \\
\ddot{\phi}_{i 3} \\
\ddot{\phi}_{i 4}
\end{array}\right]} \\
& +\left[\begin{array}{ccc}
k_{i 2} & 0 & 0 \\
0 & k_{i 3} & 0 \\
0 & 0 & k_{i 4}
\end{array}\right]\left[\begin{array}{l}
\phi_{i 2} \\
\phi_{i 3} \\
\phi_{i 4}
\end{array}\right]=\mathbf{0}
\end{aligned}
$$

ここで

$$
\begin{aligned}
M_{11}= & m_{i 2} s_{i 2}^{2}+m_{i 3}\left(l_{i 2}+s_{i 3}\right)^{2}+m_{i 4}\left(l_{i 2}+l_{i 3}+s_{i 4}\right)^{2} \\
& +I_{i 2}+I_{i 3}+I_{i 4} \\
M_{12}= & m_{i 3}\left(s_{i 3}^{2}+l_{i 2} s_{i 3}\right) \\
& +m_{i 4}\left(l_{i 2}+l_{i 3}+s_{i 4}\right)\left(l_{i 3}+s_{i 4}\right)+I_{i 3}+I_{i 4} \\
M_{13}= & m_{i 4}\left(s_{i 4}^{2}+l_{i 2} s_{i 4}+l_{i 3} s_{i 4}\right)+I_{i 4}
\end{aligned}
$$

†この方法は，アームを個々のリンクに分解することを前提としている アームを分解することが望ましくない場合，またはそれが不可能な場 合にも，仮想受動関節モデルを用いてアーム全体を一度にモデル化す ることは可能である。この場合には，多くの受動関節をもった多関節 剛体アームの動特性同定問題に帰着される。一般には，決定すべきパ ラメータが多いので, 同定試験法扔よび得られるデー夕の処理法に種々 の配慮が必要となるであろうが，フレキシブルなリンクの数が1本な いし 2 本の場合にはさほど困難なくモデルが得られる可能性がある。 さらに，アームを分解しない場合でも，各関節の位置と姿勢，お上び そこで加えられる力とモーメントの情報が得られるならば，アーム全 体の適当な同定実験のデータから，各リンクを独立にモデル化するこ とも可能である。

†各リンク $i$ の仮想リンク数 $N_{i}$ をいつに選ぶかは, 本来, 全体とし てどのような目的に対して有効なモデルとするかという判断に基ついい て決定するのが望ましい。本実験例では第 3 固有振動数までをモデル 化できる程度のモデルということで $N_{i}=4$ としており，このような モデル化の目的の検討までには立ち入っていない。これは今後の課題 である。

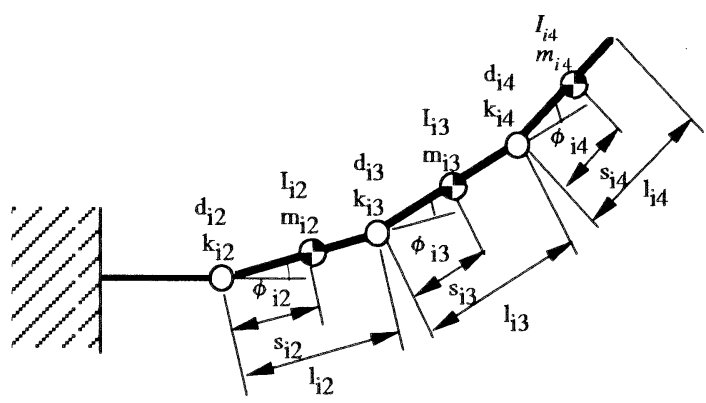

Fig. 5 Model of clamped-free flexible link

$$
\begin{aligned}
& M_{22}=m_{i 3} s_{i 3}^{2}+m_{i 4}\left(l_{i 3}+s_{i 4}\right)^{2}+I_{i 3}+I_{i 4} \\
& M_{23}=m_{i 4}\left(s_{i 4}^{2}+l_{i 3} s_{i 4}\right)+I_{i 4} \\
& M_{33}=m_{i 4} s_{i 4}^{2}+I_{i 4}
\end{aligned}
$$

ただし， $m_{i j}, l_{i j}, s_{i j}, I_{i j}$ はそれぞれ仮想りンク $(i, j)$ の質 量，リンク長，重心位置，重心回りの回転慣性モーメント， $\phi_{i j}$ は仮想受動関節 $(i, j)$ の関節变位角であり Fig. 5 に示すような 角度とする。また $k_{i j}$ は仮想受動関節 $(i, j)$ のバネ定数である。

リンク $i$ のモデルの第 $j$ 固有角振動数を $\omega_{i j}$ とすると, $\omega_{i j}$ は式 (2) より，

$$
c_{a} \omega_{i j}^{6}+c_{b} \omega_{i j}^{4}+c_{c} \omega_{i j}^{2}+c_{d}=0
$$

となる関係を満たさなければならない。ここで

$$
\begin{aligned}
c_{a}= & M_{11} M_{23}^{2}+M_{22} M_{13}^{2}+M_{33} M_{12}^{2} \\
& -M_{11} M_{22} M_{33}-2 M_{12} M_{13} M_{23} \\
c_{b}= & \left(M_{22} M_{33}-M_{23}^{2}\right) k_{i 2}+\left(M_{11} M_{33}-M_{13}^{2}\right) k_{i 3} \\
& +\left(M_{11} M_{22}-M_{12}^{2}\right) k_{i 4} \\
c_{c}= & -k_{i 2} k_{i 3} M_{33}-k_{i 3} k_{i 4} M_{11}-k_{i 4} k_{i 2} M_{22} \\
c_{d}= & k_{i 2} k_{i 3} k_{i 4}
\end{aligned}
$$

である。

次に静特性について考える。リンクの静的特性を示す指標と しては種々のものが考えられるが，本論文では先端に集中荷重， 集中モーメントをかけた際の先端変位，变位角とする。Fig. 3 のような柔軟なリンクの根元を固定し, 先端に集中荷重 $P$ をか けたときの先端の変位，変位角をそれぞれ $\mu_{P}, \varphi_{P}$, 集中モ一 メント $M$ をかけたときの先端の変位，変位角をそれぞれ $\mu_{M}$, $\varphi_{M}$ とすると，

$$
\begin{aligned}
& {\left[\begin{array}{c}
\mu_{P} / P \\
\varphi_{P} / P \\
\mu_{M} / M \\
\varphi_{M} / M
\end{array}\right]=\boldsymbol{H}\left[\begin{array}{c}
1 / k_{i 2} \\
1 / k_{i 3} \\
1 / k_{i 4}
\end{array}\right]} \\
& \boldsymbol{H}=\left[\begin{array}{ccc}
\left(l_{i 2}+l_{i 3}+l_{i 4}\right)^{2} & \left(l_{i 3}+l_{i 4}\right)^{2} & l_{i 4}^{2} \\
l_{i 2}+l_{i 3}+l_{i 4} & l_{i 3}+l_{i 4} & l_{i 4} \\
l_{i 2}+l_{i 3}+l_{i 4} & l_{i 3}+l_{i 4} & l_{i 4} \\
1 & 1 & 1
\end{array}\right]
\end{aligned}
$$

となる 


\section{3 パラメータ決定法}

本節では，仮想受動関節モデルのパラメータ決定法について 説明する [7]. まず式 (1) の $\boldsymbol{\alpha}_{r}$ として

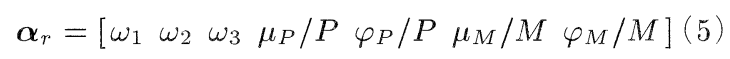

をとり，式（1）を最小とするようなパラメータを求めるパラ メータとする.ここで $\omega_{i}$ は実機のリンクの固有振動数である. パラメータ決定に際しては，実際のアームを仮想的に切断し， そこに受動関節をつけると考えることとする。すると自由に選 ベるパラメータは $l_{i j}, k_{i j}$ のみで, その他の $m_{i j}, I_{i j}, s_{i j}$ な どはアームの形状と質量分布により決定されるため $l_{i j}$ の関数 となる。一般に式（1）を最小とするようなパラメータを解析 的に求めることは困難であるが, 大略以下のような数值的な最 適值探索アルゴリズムによって各パラメータを求めることがで きる。

i. $l_{i 2}, l_{i 3}, l_{i 4}, k_{i 2}, k_{i 3}, k_{i 4}$ の初期值を与える.

ii. 式 (3), (4) から $\boldsymbol{\alpha}_{m}$ を求める.

iii. 式 (1) より $J$ を算出する。

iv. $l_{i 2}, l_{i 3}, l_{i 4}, k_{i 2}, k_{i 3}, k_{i 4}$ を適当な刻みで増減させ ii.に 戻る.

v. $J$ が最小となる $l_{i 2}, l_{i 3}, l_{i 4}, k_{i 2}, k_{i 3}, k_{i 4}$ の值を最適值 として採用する。

本論文の数值計算では，ステップivはオペレータの手作業で 行った。すなわち，まず粗い刻み幅で極小值の存在しそうな領 域を選定し，その領域を順次細かく絞り达んでゆくという方法 で求めた。以上に述べた方法では，簡単のため減衰に関しては 無視しているため仮想受動関節 $(i, j)$ の減衰係数 $d_{i j}$ は得られ ない. $d_{i j}$ は上記の方法でそれ以外のパラメー夕を決定した後, 実機の振動波形とモデルのシミュレーションから得られる波形 とが似るように試行錯謴的に決定する。

また，本論文では $\boldsymbol{w}=\left[w_{1}, w_{2}, \cdots, w_{7}\right]$ については

$$
\boldsymbol{w}=\left[\begin{array}{lllllll}
100 / 3 & 100 / 3 & 100 / 3 & 1 / 4 & 1 / 4 & 1 / 4 & 1 / 4
\end{array}\right]
$$

とする。これはデータへの重みとして, 動特性值群と静特性值 群の比を $100: 1$ とし, 各特性值群内では均等な重みを与える ようにしたものである。

上述の方法を用いて得られたパラメータとその場合のモデル の特性值 $\boldsymbol{\alpha}_{m}$ を Table 1 (a), (b) に示す。

\section{4 複数の境界条件に対する力学的特性を考慮したパラ メ一夕決定法}

前節で示したパラメータ決定法は Fig. 3 のような一端が固定 された単一のリンクのモデルのパラメータとしては適当である。 しかし例えば，前節で得られたパラメータをそのまま用いて固 定端と自由端を逆にした場合は， $l_{i 4}$ が固定端に， $l_{i 1}$ が自由端 になり，モデルの特性值は $l_{i 1}$ が固定端で， $l_{i 4}$ が自由端のとき とまったく異なったものとなる。前節でモデル化した実機のリ ンクは一様なリンクなので, このように固定端, 自由端を変え ても力学的特性は変化しない。このように前節のパラメータ決 定法は力学的特性の対称性については考慮されていない. 実際 のアームは複数のリンクを連結して構成されており, リンクの
Table 1 (a) Parameters of the virtual joint model (Nonsymmetric parameter)

(i) Virtual rigid links

\begin{tabular}{|c|c|c|c|c|}
\hline & $(1,1)$ & $(1,2)$ & $(1,3)$ & $(1,4)$ \\
\hline Length: $l_{1 i}(\mathrm{~m})$ & 0.077 & 0.213 & 0.222 & 0.103 \\
Gravity center: $s_{1 i}(\mathrm{~m})$ & 0.039 & 0.107 & 0.111 & 0.076 \\
Mass: $m_{1 i}(\mathrm{~kg})$ & 0.081 & 0.223 & 0.233 & 0.238 \\
Inertia: $I_{1 i}\left(10^{-4} \mathrm{~kg} \cdot \mathrm{m}^{2}\right)$ & 40.7 & 8.47 & 9.58 & 2.22 \\
\hline & $(2,1)$ & $(2,2)$ & $(2,3)$ & $(2,4)$ \\
\hline & 0.001 & 0.244 & 0.289 & 0.079 \\
Length: $l_{2 i}(\mathrm{~m})$ & 0.0005 & 0.122 & 0.145 & 0.062 \\
Gravity center: $s_{2 i}(\mathrm{~m})$ & 0.0004 & 0.098 & 0.116 & 0.092 \\
Mass: $m_{2 i}(\mathrm{~kg})$ & 0.0001 & 48.5 & 80.5 & 4.11 \\
Inertia: $I_{2 i}\left(10^{-5} \mathrm{~kg} \cdot \mathrm{m}^{2}\right)$ & 0.5 & &
\end{tabular}

(ii) Virtual passive joints

\begin{tabular}{|c|c|c|c|}
\hline & $(1,2)$ & $(1,3)$ & $(1,4)$ \\
\hline Spring constant: $k_{1 i}\left(10^{2} \frac{\mathrm{N} \cdot \mathrm{m}}{\mathrm{rad}}\right)$ & 12.8 & 9.89 & 10.7 \\
Damping coefficient: $d_{1 i}\left(\frac{\mathrm{N} \cdot \mathrm{m} \cdot \mathrm{s}}{\mathrm{rad}}\right)$ & 0.65 & 0.001 & 0.005 \\
\hline & $(2,2)$ & $(2,3)$ & $(2,4)$ \\
\hline Spring constant: $k_{2 i}\left(10^{2} \frac{\mathrm{N} \cdot \mathrm{m}}{\mathrm{rad}}\right)$ & 2.44 & 1.99 & 1.32 \\
Damping coefficient: $d_{2 i}\left(\frac{\mathrm{N} \cdot \mathrm{m} \cdot \mathrm{s}}{\mathrm{rad}}\right)$ & 0.10 & 0.008 & 0.010 \\
\hline
\end{tabular}

(b) Characteristics of the real link and model

\begin{tabular}{|c|c|c|c|c|}
\hline & \multicolumn{2}{|c|}{ Link 1 } & \multicolumn{2}{c|}{ Link 2 } \\
\cline { 2 - 5 } & $\boldsymbol{\alpha}_{\boldsymbol{r}}$ & $\boldsymbol{\alpha}_{\boldsymbol{m}}$ & $\boldsymbol{\alpha}_{\boldsymbol{r}}$ & $\boldsymbol{\alpha}_{\boldsymbol{m}}$ \\
\hline$\mu_{P} / P:\left(10^{-4} \mathrm{~m} / \mathrm{N}\right)$ & 2.75 & 3.43 & 17.0 & 22.6 \\
$\varphi_{P} / P:\left(10^{-4} \mathrm{rad} / \mathrm{N}\right)$ & 5.97 & 8.78 & 46.0 & 51.6 \\
$\mu_{M} / M:\left(10^{-4} \mathrm{~N}^{-1}\right)$ & 8.24 & 8.05 & 31.6 & 47.4 \\
$\varphi_{M} / M:\left(10^{-3} \mathrm{rad} / \mathrm{N} \cdot \mathrm{m}\right)$ & 4.64 & 2.73 & 22.0 & 16.7 \\
$\omega_{1} / 2 \pi:(\mathrm{Hz})$ & 16.1 & 16.2 & 9.28 & 9.41 \\
$\omega_{2} / 2 \pi:(\mathrm{Hz})$ & 114.7 & 114.8 & 69.3 & 69.3 \\
$\omega_{3} / 2 \pi:(\mathrm{Hz})$ & 338.9 & 339.3 & 203.2 & 203.0 \\
\hline
\end{tabular}

動的挙動は雨端からの影響を受けると考えられる。ゆえ，前節 のようなパラメータ決定法では, 特に多リンクアームのモデル 化の際，よいモデルが得られなくなるのではないかと推測され る。そこで本節では多リンクアームのモデルのパラメータとし て有効となるように，境界条件が逆転した場合の力学的特性も 考慮したパラメータ決定法について考察する.

今回用いたリンクは断面積も変化せず材質も一様であるので, 境界条件が逆転した場合を考えることは力学的特性が左右対称 であるという制約を設けることに相当する。よって Fig. 3 のよ うなモデルにおいて仮想剛体リンクのリンク長は, リンク $i$ の 全長を $L_{i}$ とすると

$$
\begin{aligned}
& l_{i 1}=l_{i 4} \\
& l_{i 2}=l_{i 3}=L_{i} / 2-2 \cdot l_{i 1}
\end{aligned}
$$

となり，仮想受動関節においても

$$
k_{i 2}=k_{i 4}, d_{i 2}=d_{i 4}
$$

となる。その他の手順および評価関数は 3.3 節のものと同一の ものを用いることができる。

この方法を用いて得られたパラメータとその場合のモデルの 特性值を Table $2(\mathrm{a})$, (b) に示す. 3.3 節で得られたパラメー 夕に比べ, 特性值の誤差が, 特に静特性において, わずかだが 大きくなっている。 
なお一様でないリンクの場合には，右端を固定した場合の特 性值および左端を固定した場合の特性值を計測し，それらすべ ての特性值を合わせたものを式（1）の $\boldsymbol{\alpha}_{r}$ とすればよい。同 様の方法で,さらにより多様な境界条件のもとでの特性值も考 慮することができる。例えば，リンク両端を回転自由な単純支 持としリンク中央位置に外力を加えたり, リンクの右端を自由 とし左端に正弦波状位置姿勢入力を加えたりしたときの自由端 の周波数応答特性值や, 先述の左端固定右端自由の静特性試験 において, リンクの途中の数点における变位と変位角を特性值 $\boldsymbol{\alpha}_{r}$ に追加することなどが考えられる。これらは，多様な境界 条件に対して平均的に有効であるようなモデルを求めることに 相当する。

\section{5 運動方程式}

前節までのようにモデル化された二つのリンクを連結して全 体の系のモデルとし，Fig. 2 に示すような平面 2 自由度 2 リン クフレキシブルアームの運動方程式を求める。

仮想リンクは剛体であると仮定しているので，この場合の運 動方程式は平面 2 自由度 8 リンク剛体マニピュレー夕の運動方 程式と関節駆動トルク以外の項は等しくなる。仮想受動関節は バネとダンパにより構成されていることから関節に作用する力 も容易に求められる。能動関節 $i$ の関節变位を $\theta_{i}$, 関節駆動卜 ルクを $\tau_{i}$ とすると, 運動方程式は

$$
M(q) \ddot{q}+h(q, \dot{q})+g(q)+K \boldsymbol{q}+\boldsymbol{D} \dot{q}=\tau
$$

Table 2 (a) Parameters of the virtual joint model (Symmetric parameter)

(i) Virtual rigid links

\begin{tabular}{|c|c|c|c|c|}
\hline & $(1,1)$ & $(1,2)$ & $(1,3)$ & $(1,4)$ \\
\hline Length: $l_{1 i}(\mathrm{~m})$ & 0.103 & 0.197 & 0.197 & 0.118 \\
Gravity center: $s_{1 i}(\mathrm{~m})$ & 0.052 & 0.099 & 0.099 & 0.086 \\
Mass: $m_{1 i}(\mathrm{~kg})$ & 0.108 & 0.207 & 0.207 & 0.254 \\
Inertia: $I_{1 i}\left(10^{-4} \mathrm{~kg} \cdot \mathrm{m}^{2}\right)$ & 0.97 & 6.70 & 6.70 & 3.26 \\
\hline & $(2,1)$ & $(2,2)$ & $(2,3)$ & $(2,4)$ \\
\hline & 0.099 & 0.201 & 0.201 & 0.112 \\
Length: $l_{2 i}(\mathrm{~m})$ & 0.050 & 0.101 & 0.101 & 0.085 \\
Gravity center: $s_{2 i}(\mathrm{~m})$ & 0.040 & 0.080 & 0.080 & 0.105 \\
Mass: $m_{2 i}(\mathrm{~kg})$ & 2.71 & 2.71 & 1.13 \\
Inertia: $I_{2 i}\left(10^{-4} \mathrm{~kg} \cdot \mathrm{m}^{2}\right)$ & 0.325 & 2.71 & &
\end{tabular}

(ii) Virtual passive joints

\begin{tabular}{|c|c|c|c|}
\hline & $(1,2)$ & $(1,3)$ & $(1,4)$ \\
\hline Spring constant: $k_{1 i}\left(10^{2} \frac{\mathrm{N} \cdot \mathrm{m}}{\mathrm{rad}}\right)$ & 11.2 & 8.96 & 11.2 \\
Damping coefficient: $d_{1 i}\left(\frac{\mathrm{N} \cdot \mathrm{m} \cdot \mathrm{s}}{\mathrm{rad}}\right)$ & 0.57 & 0.10 & 0.57 \\
\hline & $(2,2)$ & $(2,3)$ & $(2,4)$ \\
\hline & 1.53 & 1.38 & 1.53 \\
\hline Spring constant: $k_{2 i}\left(10^{2} \frac{\mathrm{N} \cdot \mathrm{m}}{\mathrm{rad}}\right)$ & 0.08 & 0.01 & 0.08 \\
\hline
\end{tabular}

(b) Characteristics of the real link and model

\begin{tabular}{|c|c|c|c|c|}
\hline & \multicolumn{2}{|c|}{ Link 1 } & \multicolumn{2}{c|}{ Link 2 } \\
\cline { 2 - 5 } & $\boldsymbol{\alpha}_{\boldsymbol{r}}$ & $\boldsymbol{\alpha}_{\boldsymbol{m}}$ & $\boldsymbol{\alpha}_{\boldsymbol{r}}$ & $\boldsymbol{\alpha}_{\boldsymbol{m}}$ \\
\hline$\mu_{P} / P:\left(10^{-4} \mathrm{~m} / \mathrm{N}\right)$ & 2.75 & 3.57 & 17.0 & 25.2 \\
$\varphi_{P} / P:\left(10^{-4} \mathrm{rad} / \mathrm{N}\right)$ & 5.97 & 9.49 & 46.0 & 66.0 \\
$\mu_{M} / M:\left(10^{-4} \mathrm{~N}^{-1}\right)$ & 8.24 & 8.71 & 31.6 & 61.0 \\
$\varphi_{M} / M:\left(10^{-3} \mathrm{rad} / \mathrm{N} \cdot \mathrm{m}\right)$ & 4.64 & 2.90 & 22.0 & 20.3 \\
$\omega_{1} / 2 \pi:(H z)$ & 16.1 & 16.1 & 9.28 & 9.34 \\
$\omega_{2} / 2 \pi:(H z)$ & 114.7 & 115.6 & 69.3 & 70.3 \\
$\omega_{3} / 2 \pi:(H z)$ & 338.9 & 342.1 & 203.2 & 207.8 \\
\hline
\end{tabular}

となる。たたし $\boldsymbol{M}$ は慣性項, $\boldsymbol{h}$ は遠心力，コリオリ力などの 非線形項, $\boldsymbol{g}$ は重力項であり

$$
\begin{aligned}
& \boldsymbol{q}=\left[\begin{array}{llllllll}
\theta_{1} & \phi_{12} & \phi_{13} & \phi_{14} & \theta_{2} & \phi_{22} & \phi_{23} & \phi_{24}
\end{array}\right]^{T} \\
& \boldsymbol{\tau}=\left[\begin{array}{llllllll}
\tau_{1} & 0 & 0 & 0 & \tau_{2} & 0 & 0 & 0
\end{array}\right]^{T} \\
& \boldsymbol{K}=\operatorname{diag}\left[\begin{array}{llllllll}
0 & k_{12} & k_{13} & k_{14} & 0 & k_{22} & k_{23} & k_{24}
\end{array}\right] \\
& \boldsymbol{D}=\operatorname{diag}\left[\begin{array}{llllllll}
0 & d_{12} & d_{13} & d_{14} & 0 & d_{22} & d_{23} & d_{24}
\end{array}\right]
\end{aligned}
$$

である。

\section{4. 分布定数系モデル}

\section{1 運動方程式}

本論文では仮想受動関節モデルの比較対象として分布定数系 モデルを用いる。そこでまず本章では分布定数系モデルを用い て前章と同じ平面 2 自由度 2 リンクフレキシブルアームをモデ ル化し，運動方程式を求める [2] [3]．Fig.6 に示すように台座 に基準座標系 $\Sigma_{0}$ を固定し， $\Sigma_{0}$ からみたリンク $i$ 上の任意の 点の位置ベクトルを $\boldsymbol{p}_{\boldsymbol{i}}$ とする。 $\boldsymbol{p}_{\boldsymbol{i}}$ は関節 $i$ の変位角 $\theta_{i}$, リ ンク $i$ の根元からの距離 $x_{i}$, リンク $i$ の長さ $L_{i}$, リンク $i$ の $x_{i}$ におけるリンクの弾性変位 $y_{i}\left(x_{i}, t\right)$ を用いて

$$
\begin{array}{r}
\boldsymbol{p}_{\mathbf{1}}\left(x_{1}, t\right)=\left[\begin{array}{l}
x_{1} \cos \theta_{1}-y_{1}\left(x_{1}, t\right) \sin \theta_{1} \\
x_{1} \sin \theta_{1}+y_{1}\left(x_{1}, t\right) \cos \theta_{1}
\end{array}\right] \\
\boldsymbol{p}_{\mathbf{2}}=\boldsymbol{p}_{\mathbf{1}}\left(L_{1}, t\right)+\left[\begin{array}{l}
x_{2} C_{12 p}-y_{2}\left(x_{2}, t\right) S_{12 p} \\
x_{2} S_{12 p}+y_{2}\left(x_{2}, t\right) C_{12 p}
\end{array}\right]
\end{array}
$$

と表される。ただし

$$
\begin{aligned}
C_{12 p} & =\cos \left(\theta_{1}+\psi_{1}+\theta_{2}\right) \\
S_{12 p} & =\sin \left(\theta_{1}+\psi_{1}+\theta_{2}\right) \\
\psi_{i} & =\left.\frac{\partial y_{i}\left(x_{i}, t\right)}{\partial x_{i}}\right|_{x_{i}=L_{i}} \quad(i=1,2)
\end{aligned}
$$

である。ここで $y_{i}\left(x_{i}, t\right)$ はモード展開法により

$$
y_{i}\left(x_{i}, t\right)=\sum_{j=1}^{n_{i}} \xi_{i j}\left(x_{i}\right) e_{i j}(t)
$$

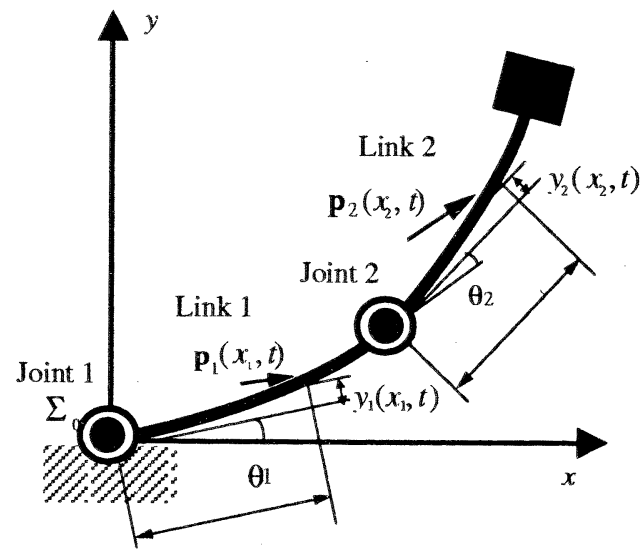

Fig. 6 Model of a planer 2-DOF flexible manipulator using distributed parameter model 
と表されるとする。ただし $n_{i}$ は仮定する振動モードの数, $\xi_{i j}\left(x_{i}\right)$ はリンク $i$ の第 $j$ 振動モードのモード関数, $e_{i j}(t)$ は それに対応するモード振幅である。本論文ではモード関数は近 似的に先端に質量がある場合の Euler-Bernoulli 梁の一端固定 他端自由モデルにより得られるものとする。

以上からアームの運動エネルギー $T$ は

$$
\begin{aligned}
2 T= & \sum_{i=1}^{2} \rho_{i} A_{i} \int_{0}^{L_{i}} \dot{\boldsymbol{p}}_{\boldsymbol{i}}^{T} \dot{\boldsymbol{p}}_{\boldsymbol{i}} d x_{i}+\sum_{i=1}^{2} M_{i} \dot{\boldsymbol{r}}_{\boldsymbol{i}}^{T} \dot{\boldsymbol{r}}_{\boldsymbol{i}} \\
& +I_{m 1}\left(\dot{\theta_{1}}+\dot{\psi_{1}}\right)^{2}+I_{m 2}\left(\dot{\theta_{1}}+\dot{\psi_{1}}+\dot{\theta_{2}}+\dot{\psi_{2}}\right)^{2} \\
& +J_{1}{\dot{\theta_{1}}}^{2}+J_{2}\left(\dot{\theta_{1}}+\dot{\psi}_{1}+\dot{\theta}_{2}\right)^{2}
\end{aligned}
$$

ポテンシャルエネルギー $V$ は

$$
\begin{aligned}
2 V= & \sum_{i=1}^{2} \rho_{i} A_{i} g \int_{0}^{L_{i}} \boldsymbol{p}_{\boldsymbol{i}}^{\boldsymbol{T}}\left[\begin{array}{ll}
0 & 1
\end{array}\right]^{T} d x_{i}+\sum_{i=1}^{2} M_{i} g \boldsymbol{r}_{\boldsymbol{i}}^{\boldsymbol{T}}\left[\begin{array}{ll}
0 & 1
\end{array}\right]^{T} \\
& +\sum_{i=1}^{2} E_{i} I_{i} \int_{0}^{L_{i}}\left\{y_{i}^{\prime \prime}\left(x_{i}\right)\right\}^{2} d x_{i}
\end{aligned}
$$

と求められる。ただし $\rho_{i}, A_{i}, J_{i}, E_{i}, I_{i}$ はそれぞれリンク $i$ の密度, 断面積, 慣性モーメント, ヤング率, 断面二次モーメ ントであり, $M_{i}, \boldsymbol{r}_{\boldsymbol{i}}, I_{m i}$ はリンク $i$ の先端の質量とその位置 ベクトル，慣性モーメントである。また $g$ は重力加速度である．

(18), (19) よりラグランジュの方法から運動方程式は

$$
M_{d}\left(\boldsymbol{q}_{d}\right) \ddot{q_{d}}+h_{d}\left(\boldsymbol{q}_{d}, \dot{q}_{d}\right)+g_{d}\left(\boldsymbol{q}_{d}\right)+D_{d} \dot{q_{d}}+K_{d} q_{d}=\tau_{d}
$$

となる．ただし $M_{d}$ は慣性項， $h_{d}$ はコリオリカなどの非線 形項, $g_{d}$ は重力項, $K_{d}$ は復元力の項, $D_{d}$ は減衰項であり, $q_{d}, \tau_{d}$ は

$$
\begin{aligned}
\boldsymbol{q}_{\boldsymbol{d}} & =\left[\begin{array}{llllllll}
\theta_{1} & \theta_{2} & e_{11} & \ldots & e_{1 n_{1}} & e_{21} & \ldots & e_{2 n_{2}}
\end{array}\right]^{T}(21) \\
\boldsymbol{\tau}_{\boldsymbol{d}} & =\left[\begin{array}{llll}
\tau_{1} & \tau_{2} & \mathbf{o}
\end{array}\right]^{T}
\end{aligned}
$$

である。

4.2 パラメータの值について

分布定数系モデルのパラメータとしては $L_{i}, \rho_{i}, A_{i}, J_{i}, E_{i}$, $I_{i}$ があるが, $E_{i}$ 以外の值はアームの形状と質量分布から求め ることができる。ヤング率 $E_{i}$ は一般には材質から決定される 值をそのまま用いることが多い上うであるが，本論文ではその 值を 3 章で測定した実機の特性值から以下の手順で求めること で，仮想受動関節モデルと対応させる。

式 (5) の特性值 $\boldsymbol{\alpha}_{\boldsymbol{r}}$ の各要素 $\alpha_{r i}$ から求められるヤング率 の値を $E_{\alpha_{r i}}$ と表す.

まずリンクの動特性值 $\omega_{i}$ については，一端固定他端自由で 先端に質量 $M$ がある場合

$$
\omega_{i}^{2}=\frac{\beta_{i}^{4}}{\rho A} E I
$$

で与えられる。ただし $\beta_{i}$ は

$$
\begin{array}{r}
M \beta\{\cosh (\beta L) \sin (\beta L)-\sinh (\beta L) \cos (\beta L)\} \\
-\rho A\{1+\cosh (\beta L) \cos (\beta L)\}=0
\end{array}
$$

Table 3 Parameters of the distributed parameter model

\begin{tabular}{|c|c|c|}
\hline & Link 1 & Link2 \\
\hline Length $(\mathrm{m})$ & 0.615 & 0.613 \\
Density $\left(\mathrm{kg} / \mathrm{m}^{3}\right)$ & $7.94 \times 10^{3}$ & $7.94 \times 10^{3}$ \\
Cross Section(m) & $1.32 \times 10^{-4}$ & $5.03 \times 10^{-5}$ \\
Young's Modulus(GPa) & $1.70 \times 10^{2}$ & $1.65 \times 10^{2}$ \\
Inertia(kg.m $\left.{ }^{2}\right)$ & $1.89 \times 10^{-2}$ & $7.17 \times 10^{-3}$ \\
Damping coefficient(s) & $1.5 \times 10^{-4}$ & $1.4 \times 10^{-4}$ \\
\hline
\end{tabular}

の第 $i$ 番目の正実根である. 本論文の場合， $M$ はフランジの 質量となる。よって

$$
E_{\alpha_{r i}}=\frac{\rho A \omega_{i}^{2}}{\beta_{i}^{4} I} \quad(i=1,2,3)
$$

と求まる。

次にリンクの静特性值については

$$
\begin{aligned}
& {\left[\begin{array}{llll}
\mu_{P} / P & \varphi_{P} / P & \mu_{M} / M & \varphi_{M} / M
\end{array}\right]} \\
& \quad=\left[\begin{array}{llll}
L^{3} / 3 E I & L^{2} / 2 E I & L^{2} / 2 E I & L / E I
\end{array}\right]
\end{aligned}
$$

で与えられるので

$$
\begin{aligned}
& {\left[\begin{array}{llll}
E_{\alpha_{r 4}} & E_{\alpha_{r 5}} & E_{\alpha_{r 6}} & E_{\alpha_{r 7}}
\end{array}\right]} \\
& =\left[\begin{array}{llll}
\frac{L^{3}}{3 I \frac{\mu_{P}}{P}} & \frac{L^{2}}{2 I \frac{\varphi_{P}}{P}} & \frac{L^{2}}{2 I \frac{\mu_{M}}{M}} & \frac{L}{I \frac{\varphi_{M}}{M}}
\end{array}\right]
\end{aligned}
$$

となる。

以上のように各特性值から求められたヤング率の推定值に, 3.3 節で用いたのと同じ重み係数 $\boldsymbol{w}=\left[w_{1}, w_{2}, \cdots, w_{7}\right]$ を用い て得られる

$$
\hat{E}=\sum_{i=1}^{7} w_{i} E_{\alpha_{r i}} / \sum_{i=1}^{7} w_{i}
$$

を最終的なヤング率の值とする，得られた $\hat{E}$ を含む分布定数 系モデルのパラメー夕值を Table 3 に示す。な押，材質から 得られるヤング率はリンク 1,2 とも $2.06 \times 10^{2}[\mathrm{GPa}]$ となっ ており，かなり異なる値となっている。

\section{5. 固定関節を用いた実験およびシミュレーション}

前章までで得られた各モデルを用いてシミュレーションを行 い，実機と応答の比較をすることで仮想受動関節モデルの有効 性を検証する。まず本章では制御部の特性やアクチュエータ部 の摩擦特性などの影響を取り除く目的で，関節部にモータでは なくFig. 7 のような単にある角度を保持する関節（以後これ を固定関節と呼ぶ）を用い，2本のリンクをある姿勢に保持し て，そのリンクを振動させるという実験を行い，実機の振動の 様子とシミュレーションから得られる振動の様子を比較する。

5.1 実験およびシミュレーション

実験は固定関節を用いて 2 本のリンクを連結して平面 2 自由 度のある姿勢に保持し，その手先位置に鉛直下向きに $5.88[\mathrm{~N}]$ の力を加えて静止させた状態から，ある瞬間にその力を解放し てリンクを振動させるということを行う。その際にアーム先端 


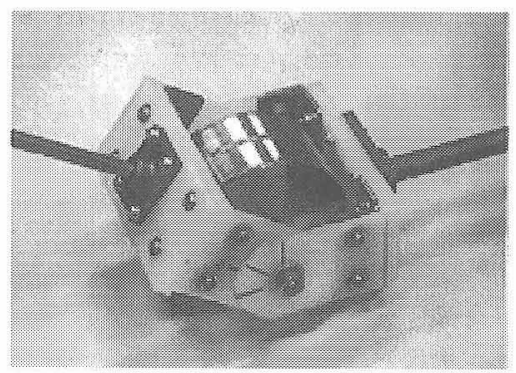

Fig. 7 A photograph of fixed-joint

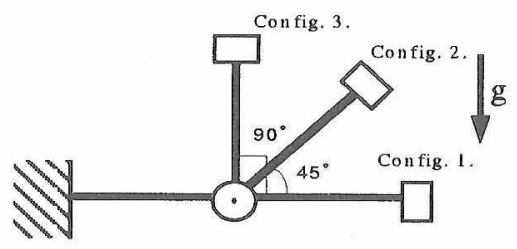

Fig. 8 Configurations of the arm in the fixed-joint experiment

Table 4 Characteristics of payload at link tip

\begin{tabular}{|c|c|c|}
\hline & of Link 1 & of Link 2 \\
\hline Mass $(\mathrm{kg})$ & 2.60 & 0.79 \\
Inertia $\left(\mathrm{kg} \cdot \mathrm{m}^{2}\right)$ & $2.63 \times 10^{-3}$ & $8.90 \times 10^{-4}$ \\
\hline
\end{tabular}

位置の加速度を観測する。またリンクの姿攀はFig.8のように 3 通りに変える。加速度計測のサンプリングタイムは $1.0[\mathrm{~ms}]$ とする。

シミュレーションでは各モデルの運動方程式 $(10),(20)$ に 扔いて能動関節の変位 $\theta_{1}, \theta_{2}$ を定数としたものを用いる。さ らに仮定として式 (10),(20) とも

- 非線形項は無視する

・変位は微小とし, 二次の微小量は無視する

とする。また本論文では仮想受動関節モデルを 4 分割モデルと したので, 変数の数を合わせるため, 分布定数系モデルでは三次 の振動モードまで考慮する。サンプリングタイムは実験と等し くし，積分のきざみ幅を 0.1 [ms] として, Runge-Kutta-Gill 法を用いる。シミュレーションで用いた各リンク先端のペイ ロードの特性值をTable 4 に示す。得られた実験およびシミュ レーションの結果を Fig.9 に示す.

\section{2 考察}

Fig. 9 を見ると，すべての場合と姿勢において，全体的な波 形に関してはシミュレーションと実機はよく一致しているとい える。実機で振動の初期に見られる高次の振動も両モデルとも 再現できている。ただし，振動の初めの振幅の大きさ，また定 常状態の振幅の大きさに関しては，仮想受動関節モデルの方が 実機に近い応答を再現している。また高次の振動に関しては， 対称パラメータの仮想受動関節モデルでは高次の振動の減衰が 実機と同程度でよく再現できているが，その他のモデルは実機 より減衰が遅くなってしまっている。
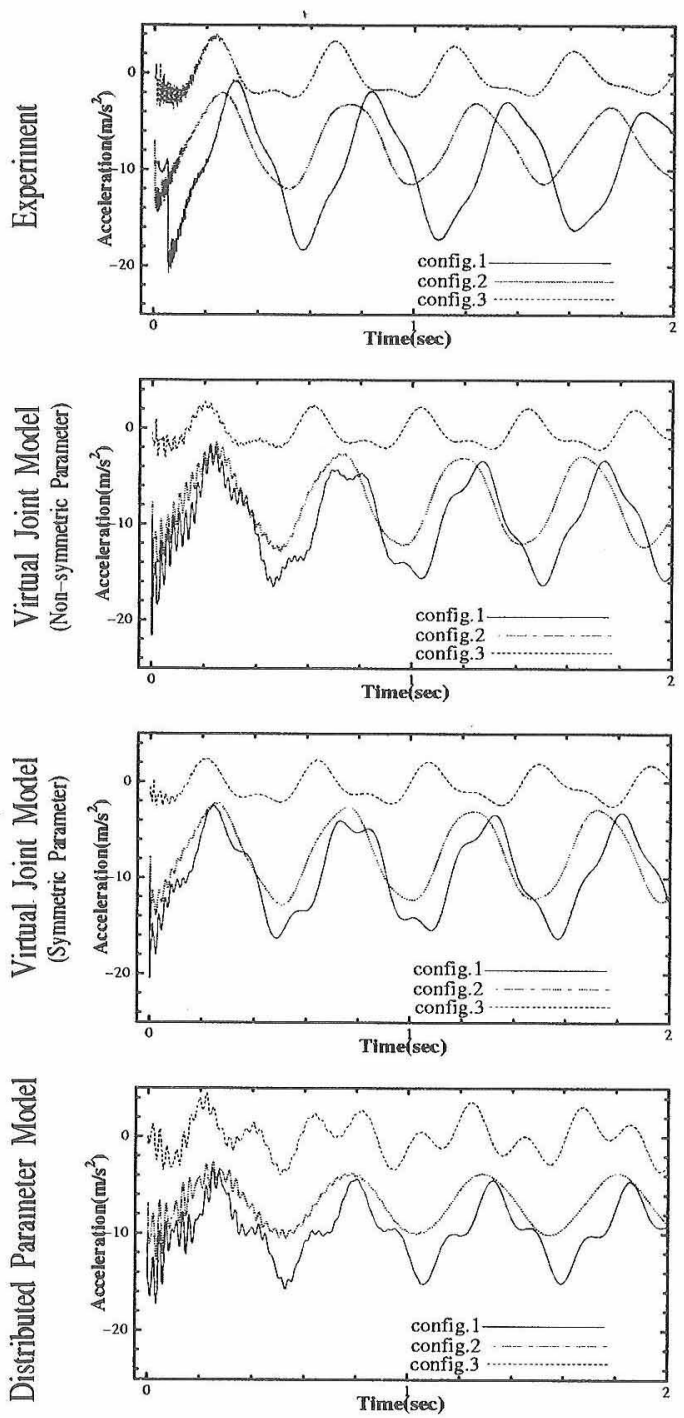

Fig.9 The result of the fixed-joint experiments and simulations

Table 5 1st natural frequencies in the fixed-joint experiments and simulations

\begin{tabular}{|c|c|c|c|c|}
\hline \multirow{2}{*}{\multicolumn{2}{|c|}{ Type }} & \multicolumn{3}{|c|}{$\begin{array}{l}\text { 1st Natural } \\
\text { frequency }(H z)\end{array}$} \\
\hline & & config. 1 & config. 2 & config. 3 \\
\hline \multicolumn{2}{|c|}{ Experiment } & 1.91 & 1.93 & 2.17 \\
\hline \multirow[t]{2}{*}{ VJM } & Non-Sym. Para. & 2.10 & 2.12 & 2.41 \\
\hline & Sym. Para. & 2.05 & 2.05 & 2.35 \\
\hline \multicolumn{2}{|r|}{ DPM } & 1.89 & 1.94 & 2.44 \\
\hline
\end{tabular}

DPM: Distributed Parameter Model

次に各場合における実機とモデルの一次の固有周波数を Table 5に示す。実機では，連絬部（肘部）の角度が大きくな るにつれ周波数が大きくなる傾向がみられる。この傾向は而モ デルとも再現できている. 
また仮想受動関節モデルのなかでは，パラメータを対称にし たものが，すべての場合で最も実機の応答に近ついており，3.4 節で述べた予測が正しかったといえる。

次に分布定数系モデルと仮想受動関節モデルとを比較する. 固有周波数に関しては config.1, 2 では分布定数系モデルが, config.3 では仮想受動関節モデルの対称なパラメータのものが 最も実機に近くなっている。実際のアームを考えると, config.1 のような腕を伸ばした姿勢にすることはまれであり，アームの モデルとしては仮想受動関節モデルも遜色ないといえるであ ろう.

以上の結果から仮想受動関節モデルは分布定数系モデルと, ある姿勢の場合は多少周波数の精度が落ちるものの, ほぼ同程 度の精度をもつことが分かる。

\section{PD 制御実験およびシミュレーション}

次に平面内を能動運動する 2 自由度 2 リンクフレキシブル アームを対象に実機の応答とシュミレーションから得られるモ デルの応答の比較を行う。振動の様子を観察することが目的で あるので，関節モー夕の制御には，特に振動を抑制するような 制御を用いず，最も基本的な制御法である $\mathrm{PD}$ 制御を適用する。 そしてアームを能動運動させた際の各関節の関節角の変化と各 リンク先端の振動を実機を用いた実験から観測し，各モデルの シミュレーションとの比較を行って, 仮想受動関節モデルの有 効性を検証する。

\section{1 実験およびシミュレーション}

実験ではアームの各関節の目標值を加速, 減速を時間の四次 多項式で近似した軌道で与え, 関節 $i$ の駆動入力 $\tau_{i}$ には次式 のような PD 制御則を適用する。

$$
\tau_{i}(t)=k_{i p}\left(\theta_{i d}(t)-\theta_{i}(t)\right)+k_{i v}\left(\dot{\theta}_{i d}(t)-\dot{\theta}_{i}(t)\right)
$$

ここで $k_{i p}, k_{i v}$ はそれぞれ関節 $i$ の位置と速度のフィードバッ クゲインであり, $\theta_{i d}$ は関節 $i$ の目標軌道である。今回の実験で は $k_{1 p}$ を $2,000[\mathrm{~N} \cdot \mathrm{m} / \mathrm{rad}], k_{1 v}$ を $250[\mathrm{~N} \cdot \mathrm{m} \cdot \mathrm{s} / \mathrm{rad}]$ とし, $k_{2 p}$ を $750[\mathrm{~N} \cdot \mathrm{m} / \mathrm{rad}], k_{2 v}$ を $45[\mathrm{~N} \cdot \mathrm{m} \cdot \mathrm{s} / \mathrm{rad}]$ とする。また関節角 については $1.0[\mathrm{sec}]$ の間に初期姿勢 $\left[\begin{array}{ll}\theta_{1} & \theta_{2}\end{array}\right]=\left[\begin{array}{ll}15^{\circ} & -5^{\circ}\end{array}\right]$ か ら, 終端姿勢 $\left[\theta_{1} \theta_{2}\right]=\left[40^{\circ} 50^{\circ}\right]$ 一動かす軌道を与える $。$ ま た, サンプリングタイムは $1.0[\mathrm{~ms}]$ とする.

シミュレーションでは各モデルの運動方程式 (10), (20) を 用いるが前章同様，仮定として式 $(10),(20)$ とも

・非線形項は無視する

・変位は微小とし，二次の微小量は無視する

とする．また仮想受動関節モデルは 4 分割モデルとし，分布定 数系モデルは三次のモードまで考慮する。仮想受動関節モデル のパラメータ值に関しては前章で最もよくモデリングできた対 称なパラメータを用いる。またアームの各関節の目標值，ゲイ ン, サンプリングタイムは実験と等しくし，積分のきざみ幅を 0.1 [ms] として, Runge-Kutta-Gill 法を用いる。シミュレー

\footnotetext{
†これ以外にも2 種類の初期および終端姿勢の組について実験を行って
} おり,これらの場合の実験結果もほとんど同じ傾向を示した。
Table 6 Characteristics of payload at link tip

\begin{tabular}{|c|c|c|}
\hline & of Link 1 & of Link 2 \\
\hline Mass $(\mathrm{kg})$ & 4.1 & 0.57 \\
Inertia $\left(\mathrm{kg} \cdot \mathrm{m}^{2}\right)$ & $1.0 \times 10^{-2}$ & $3.37 \times 10^{-4}$ \\
\hline
\end{tabular}

Table 7 Characteristics of the motors

\begin{tabular}{|c|c|c|}
\hline & Joint 1 & Joint 2 \\
\hline Inertia of Rotor $\left(\mathrm{kg} \cdot \mathrm{m}^{2}\right)$ & 7.7 & 0.75 \\
Static Friction $(\mathrm{N} \cdot \mathrm{m})$ & 8.5 & 1.9 \\
\hline
\end{tabular}

Table 8 1st natural frequencies in the PD control experiment and simulations

\begin{tabular}{|c|c|}
\hline Type & $\begin{array}{c}\text { 1st Natural } \\
\text { frequency }(\mathrm{Hz})\end{array}$ \\
\hline Experiment & 2.19 \\
\hline Virtual joint model & 2.14 \\
\hline Distributed parameter model & 2.14 \\
\hline
\end{tabular}

ションで用いた各リンクのペイロードの特性值，および関節 モータの特性值をそれぞれ Table 6,7 亿示す.

得られた実験抢よびシミュレーションの結果を Fig. 10 に 示す。

\section{2 考察}

まず関節角についてであるが，定常状態において実機・各モ デル共に振動的になっていることが分かる。また，関節 1 の関 節角では過渡状態に拈いて実機と両モデルにかなりの差が見ら れる。これはモータのシミュレートが不完全なためと思われる。 過渡状態において加速度の応答，特に振幅の大きさが実機とモ デルとでかなり異なるのはこのことが原因と思われる。

次にリンク先端の加速度についてであるが, 過渡状態では前 述したような関節角 1 の応答の違いにより，リンク 1 先端の加 速度では実機に扔いて高次の振動がみられるが各モデルとも再 現できておらず，またリンク 2 先端の加速度については実機と 両モデルとで振幅にかなりの違いがみられる。定常状態に関し てはどちらのモデルも応答をうまく再現できているといえる。 ただしンク 2 先端の加速度については実機と両モデルとで振 幅の大きさに違いがみられる。これは実機ではハーモニックド ライブ減速器の弾性による振動で振幅が増すのに対し, シミュ レーションではハーモニックドライブの弾性について考慮して いないためそうはならないためと考えられる。たたしモデルを 比較すると，仮想受動関節モデルのほうが分布定数系モデルよ り振幅が大きくより実機に近い。また減衰に関しては，実機に 比ベシミュレーションのほうが早く減衰している。これも, 害 機ではハーモニックドライブの弾性により振動が持続するため と考えられる.

次に実機と各モデルの一次の固有周波数を Table 8 に示す. 周波数に関しては本章の実験では両モデルとも同じ值となって いることが分かる。

以上の結果から，能動関節をもつ実機のアームにおいても， 仮想受動関節モデルは分布定数系モデルと同程度の精度をもつ 

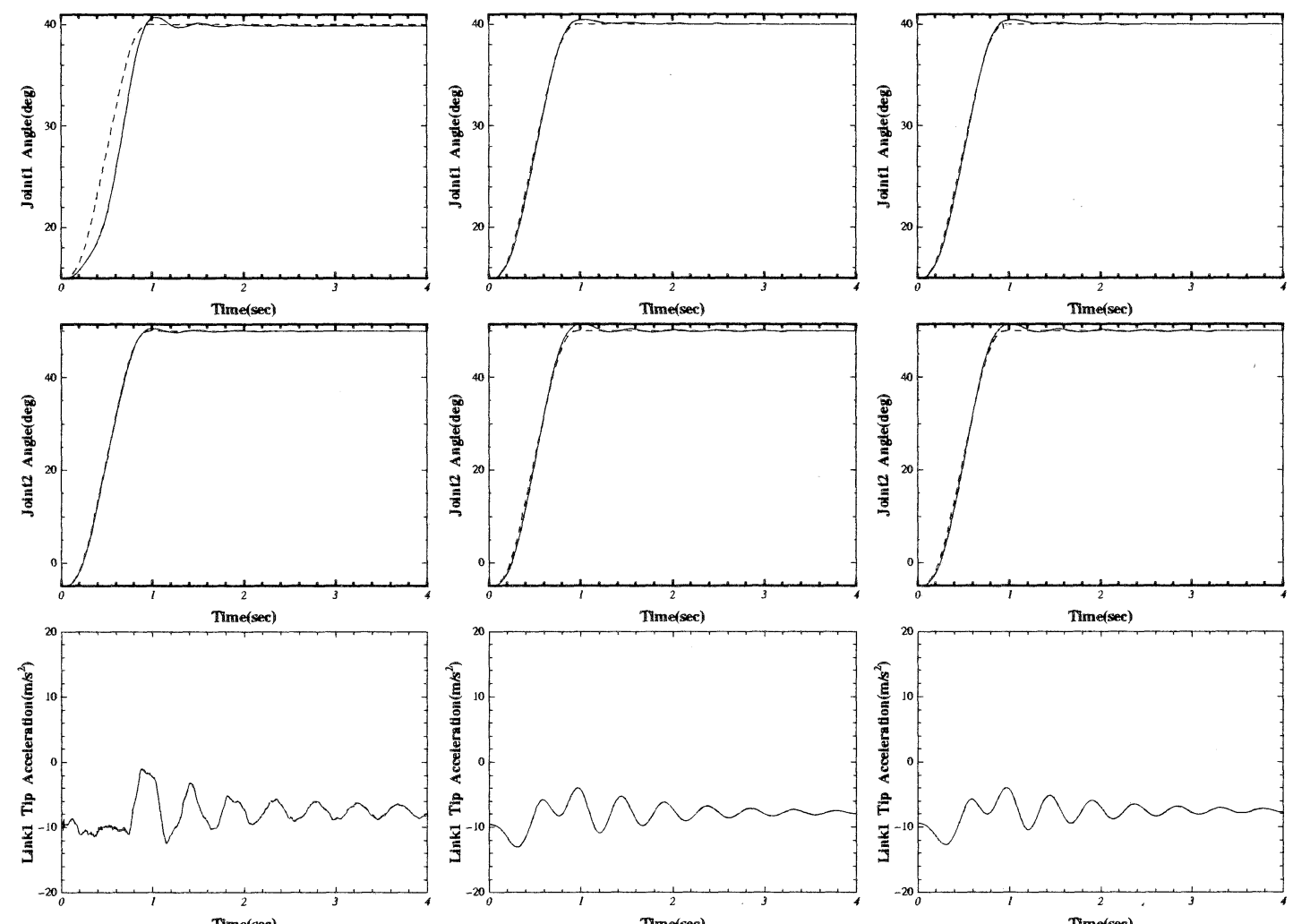

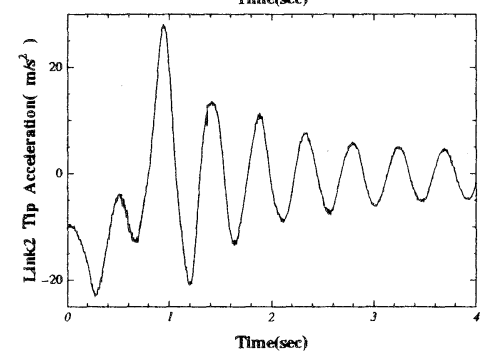

(a) Experiment

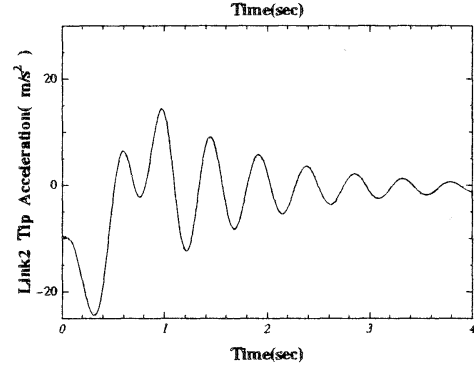

(b) Virtual Joint Model

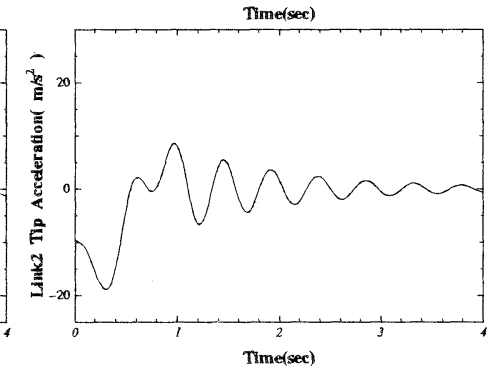

(c) Distributed Parameter Model

Fig. 10 The result of the PD control experiment and simulations

ことが示せだ．さらに分布定数系モデルの多リンク・多自由度 アームへの拡張の困難さを考慮すると, 仮想受動関節モデルは フレキシブルアームのモデリングとして有効な方法であるとい える。

\section{7.おわりに}

本論文ではフレキシブルアームに対する仮想受動関節モデル の有效性を検証を行った。そのため平面 2 自由度 2 リンクアー 厶を対象に実機，分布定数系モデル，仮想受動関節モデルの動 的応答を比較し，仮想受動関節モデルは同变数をもつ分布定数 系モデルとほほ同程度の精度をもつことを示した。以上からモ

\footnotetext{
†本報告の実験結果の評価は, 応答波形の振動の振幅と減衰, 固有振動 数，などを総合したものであり，筆者としては妥当な評価であると考え ているが，直感的主観的評価の域を出ていないことも確かである。分 布定数的動特性をもつシステムのモデリング法の，上り客観的で定量 的な評価法を確立することが望ましいが，これはモデル化の目的を定 量化するという困難な問題とも関連しており，今後の課題としたい。
}

デリングの精度，非一様なリンクもモデリングが可能 [8] とい う適用範囲の広さを考えると仮想受動関節モデルはフレキシブ ルアームのモデリングとして有效な方法であるといえる。

今後の課題としては, 上り簡便で減衰係数も一意に決定でき るパラメータ決定法の構築などが挙げられる。

\section{参 考 文 献}

[1] 坂和，松野：“フレキシブルアームのモデリングと制御”，計測と制 御, vol.25, no.1, pp.64-70, 1986.

[2] 嘉納：“フレキシブルアームの分布定数系モデル”, 日本ロボット学 会誌, vol.6, no.5, pp.430-435, 1988 .

[3] 馬，浅田，得丸：“軌道制御のためのフレキシブルロボットアームの 逆動力学”, システムと制御, vol.31, no.10, pp.764-772, 1987 .

[4] A.De Luca and B. Siciliano, "Closed Form Dynamic Model of Planar Multilink Lightweight Robots," IEEE Trans. on Sys. Man Cybernat., vol.21, no.4, pp.826-839, 1991.

[5] R. Theodore and A. Ghosal: "Comparison Of The Assumed Modes And Finite Element Models for Flexible Multilink Manipu lators," The Int. J. of Robotics Research, vol.14, no.2, 
pp.91-111, 1995.

[6]吉川, 村上, 細田：“2 本のフレキシブルリンクを有する 3 自由度 マニピュレータのモデリングと制御”, 日本ロボット学会誌, vol.9, no.1, pp.1-10, 1991

[7] 吉川, 絒田：“仮想的な㓝体リンクと受動関節を用いたフレキシブ ルアームのモデリングと制御”，計測自動制御学会諭文集，vol.27， no.12, pp.1389-1395, 1991

[8] T. Yoshikawa and K. Matsudera: "Experimental Study on Modeling and Control of Flexible Manipulators Using Virtual Joint Model," Preprints of the Fourth International Symposium on Experimental Robotics, pp.265-270, 1995.

[9] 近野, 内上：“ホルッァ法に基づくフレキシブルマニピュレータの動力 学モデリンダ", 日本ロボット学会誌, vol.12, no.7, pp.1021-1028,

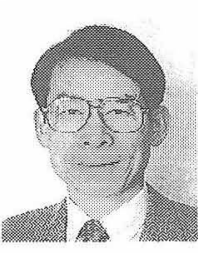

吉川恒夫 (Tuneo Yoshikawa)

1941 年 12 月 19 日生. 1969 年京都大学大学院博 士課程修了。同年同大学工学部助手。1970 年同大 学助教授. 1986 年京都大学工学部教授（1991 年よ り機械工学教室勤務)となり現在に琹る。ロボット 工学および制御工学の研究に従事。工学博士。シ ステム制御情報学会, 計測自動制御学会, 日本機 械学会, IEEEなどの正会員.
1994.

[10] 金, 近野, 内山：“フレキシブルマニピュレータ動力学の高精度集中定 数モデリング”, 日本機械学会諭文集, 62 巻 602 号, pp.4005-4011, 1996.

[11] 坂和, 松野, 他：“3 自由度フレキシブル・マニピュレータのモデリン グと加速度センサを用いた振動制御”，日本ロボット学会誌，vol.6， no.1, pp.42-51, 1988.

[12] Y. Huang and C.S.G. Lee: "Generalization of Newton-Euler Formulation of Dynamic Equations to Nonrigid Manipulators," Trans. of the ASME J. of Dynamic Systems, Measurement, and Control, vol.110, pp.308-315, 1988.

[13] 有山：振動・波動。第 5 章, 裳華房, 1970.

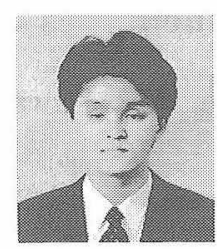

田村正人 (Masato Tamura)

1973 年 10 月 6 日生. 1996 年京都大学卒業。1998 年京都大学大学院修士課程修了。現在川崎重工業 （株）に勤務. 在学中フレキシブルアームの研究に 従事. 